\title{
Retraction
}

\section{Retracted: Phyllodes Tumor of Breast: A Review Article}

\author{
ISRN Surgery \\ Received 24 July 2013; Accepted 24 July 2013 \\ Copyright (C) 2013 ISRN Surgery. This is an open access article distributed under the Creative Commons Attribution License, which \\ permits unrestricted use, distribution, and reproduction in any medium, provided the original work is properly cited.
}

This article has been retracted as it was found to contain a substantial amount of materials, without referencing, from the article "Phyllodes tumours," by S. J. Parkera and S. A. Harriesb which was published in Postgrad Med J in 2001 doi:10.1136/pmj.77.909.428 [1].

\section{References}

[1] S. P. Mishra, S. K. Tiwary, M. Mishra, and A. K. Khanna, "Phyllodes tumor of breast: a review article," ISRN Surgery, vol. 2013, Article ID 361469, 10 pages, 2013. 